\title{
A SIMPLE ELECTRONIC DEVICE FOR MEASURING ADVANCE TIME AND WATER HEIGHT IN FURROW IRRIGATION SYSTEM
}

Guirguis, A. E. 1

\author{
S. G. Hemeda ${ }^{2}$
}

\section{ABSTRACT}

A simple electronic device was designed and created instead of traditional method for measuring advance, recession times and water heights inside and along furrows to be more convenient with an optimization method based on the volume balance approach, originally developed for estimating infiltration parameters for furrow irrigation. Field experiments were conducted at a sugar crops research stationAlexandria, where sugar beet was grown in clay soils to test the accuracy of the developed device work in measurements. The furrow irrigation inflow rates were 1.14, 1.42 and $2.25(\mathrm{l} / \mathrm{s})$. Measurement parameters included furrow geometry, slope, width, length, advance and recession times, and furrow water heights through irrigation event for each inflow rate. A volume balance method was applied to simulate water flow in the furrow system. The results obtained from the used device were compared with the field collected data by traditional method. The results showed that total advance times $\left(t_{L}\right)$ were 56.0, 42.4, and $30.5 \mathrm{~min}$, while, total recession times $\left(t_{R}\right)$ were 70.0, 53.4, and $46.0 \mathrm{~min}$, for each inflow rate, respectively. The recession time increased as inflow rate decreased; this revealed to water infiltrated into soil takes more time to disappear. Water infiltrated volume increased when inflow rate was decreased due to slow water movement along the furrow. Maximum calculated values of the infiltrated volumes $\left(V_{\text {cal }}\right)$ were $0.515,0.424$, and $0.346\left(\mathrm{~m}^{3} /\right.$ furrow length) while, minimum values were 0.353, 0.299, and 0.271 ( $\mathrm{m}^{3} /$ furrow length), by applying 1.14, 1.42 and $2.25(\mathrm{l} / \mathrm{s})$ inflow rates, respectively. The verification results between measured and calculated data showed that, the data for all the irrigation events with the optimization method using modified Kostiakov equation, fall very close to the $45^{\circ}$ line degree with deviate a little.

\footnotetext{
${ }^{1}$ Senior Researcher, Agric. Eng. Res. Inst., Agric. Res. Center, Cairo.

${ }^{2}$ Researcher, Agric. Eng. Res. Inst., Agric. Res. Center ,Cairo.
} 
This means, that the used electronic device is expected to be superior for estimating infiltration characteristics and evaluating furrow irrigation system with high accuracy.

\section{INTRODUCTION}

urface irrigation is the most extensively used way of applying irrigation water in the world. Furrow irrigation is one of the oldest methods of irrigation in which soil surface is used to convey and infiltrate water. Simplicity of design and low capital investment has contributed to its popularity. Advance and recession characteristics are the two main parameters for determining the performance of furrow irrigation. Field estimation of advance and recession times can be a difficult task.

There is no suitable technique available for measuring the recession time in furrow irrigation especially on fields with a high clay content and small longitudinal slope.

Design and management of furrow irrigation systems require, among other things, accurate estimation of the amount of water that enters the soil and its spatial distribution. Subsurface water distribution is a function of many factors, including soil hydraulic characteristics, initial water content, flow depth, furrow shape, and crop and climatic factors. A traditional way to present soil water distributions under a furrow is to determine the water content at selected locations in the subsurface domain of interest and draw contours to show water contents and distributions Abbasi et al. (2003) and Wöhling et al. (2004).

Strelkoff. And Souza (1984) reported that water depth in furrows has a primary influence on infiltration. If flow depth remains relatively constant everywhere and infiltration parameters are measured at that depth, volume infiltrated per unit length computed in a mathematical model of furrow flow depends only on the time of stream arrival. But, a significant depth gradient results in error unless the variable depth is incorporated into the infiltration computation.

Many scientists, dealt with furrow irrigation, try to improve the application efficiency by investigating the importance of the parameters 
influence the furrow irrigation. Slope, furrow length, intake family have extensively been studied. The estimation of the advance and opportunity time is alike when the altering flow rate is used. The distance that the water will advance or the quantity of water that will infiltrate is calculated at each time step. Both equations that describe infiltration and the advance of the water are nonlinear to the time. Each time step does not cause the same alteration to the distance and the cumulative infiltration. Thus, the alteration to the distance and cumulative infiltration has to be calculated at each time step, (Ampas. and Baltas 2009).

Some researchers such as: (Elliott and Walker, 1982) and (Strelkoff. and Souza 1984) used empirical equations to estimate the advance or recession function of furrow irrigation. They reported that empirical approach to furrow irrigation may not yield satisfactory results for general application. However, manual data collection is labor and time intensive and is often inaccurate due to lack of visibility of surface water at remote locations in large fields. To overcome these obstacles, an inexpensive, simple and effortless measure device should be developed and employed to measure and record water advance; recession times and water heights at multiple stations along the furrow during the irrigation event. Esfandiari and Maheshwari (1997) stated that the infiltration characteristics of a soil vary spatially and temporally, and due to this the available method for estimating the characteristics in furrow irrigation are either not suitable or have restrictions for their field use. They added that an optimization method based on the volume balance approach originally developed for estimating parameters in border irrigation was modified for furrow irrigation. Water -level probes were designed and arranged along the furrow. The water level probe and data logger were used to measure and record the flow characteristics data every one minute. Hunsaker et al. (2011) designed an inexpensive field probe to measure and record the water advance and recession times. Field evaluation of the probe performance was conducted in irrigation-furrow utilizing 40 and 26 probes in two separate field tests. They mentioned that, probes will provide acceptable advance and recession information for most surface irrigation evaluation applications. A lot of work is still 
needed to achieve the optimum conditions for measuring infiltration parameters of furrow irrigated fields.

Therefore, the specific objectives of this research were to:

1- Design, construct and calibrate a simple and effortless device for measuring and recording advance, recession times and water heights inside and along furrows.

2- Determine water infiltrated volume through irrigation event.

3- Assessment the accuracy of the data collected by the device as compared with data measured in furrow irrigation by traditional method.

\section{MATERIAL AND METHODS}

\section{Device description:}

The electronic device consists mainly of three main units: oscillator unit, converter unit and operational amplifier as shown in Fig. (1a and b).

1- Oscillator unit: is the 555 IC which, include pulse generation as shown in Fig. (1). Sensor (condenser (C) is consisted of two aluminum angles, which were supported together parallel in vertical direction on the frame. The aluminum angles dimensions were $40 \mathrm{~cm}$ length, $5 \times 5 \mathrm{~cm}$ width and $0.1 \mathrm{~cm}$ thickness as shown in Fig. (1c). While, the distance between the two aluminum angles was equal to $0.4 \mathrm{~cm}$. The capacity of this condenser $(\mathrm{C})$ depends on the horizontal distance between the aluminum angles, their cross-section area, the electrical material, and water height. The condenser (C) is charged through $\mathbf{R}_{\mathbf{1}}(1 \mathrm{~K} \Omega)$ and $\mathbf{R}_{\mathbf{2}}(10 \Omega)$, but discharges through $\mathbf{R}_{\mathbf{2}}$. Therefore the frequency was depending on the capacity of the condenser $(\mathrm{C})$. The calculated frequency can be expressed by Forrest (1989) as follows:

Frequency $=1.44 /\left(R_{1}+R_{2}\right) . C$. $)$.

2- Converter unit which converts a variable analogue input pulses (frequency) to voltage.

3- Operational amplifier which amplifies the output voltage including as a function of the water level (data). This data was recorded to the computer through data acquisition system. The Condenser (sensor) was connected with a converter device (oscillator and operation amplifier as 
shown in Fig (4). This simple device is applicable for measuring advance, recession times and water heights inside and along the furrow during irrigation, from the start to the end of irrigation event.

\section{Device calibration:}

The sensor was laboratory calibrated by taking frequent measurements of the sensor capacity versus different water levels. The following sequences were carried out for the calibration:

1-The power supply was turned on and the output comes out from the circuit was record, (the output of the sensor equal zero).

2- The sensor was put inside a graduated cylinder.

3- Water was proud inside the graduated cylinder to that height equal to one $\mathrm{cm}$ and the output data comes out from the circuit was recorded.

4- Step 3 was repeated for different water heights ranged from 1 to 24 $\mathrm{cm}$, (at every two successive water heights) and the output result comes out from the circuit for each water height in the graduated cylinder was recorded.
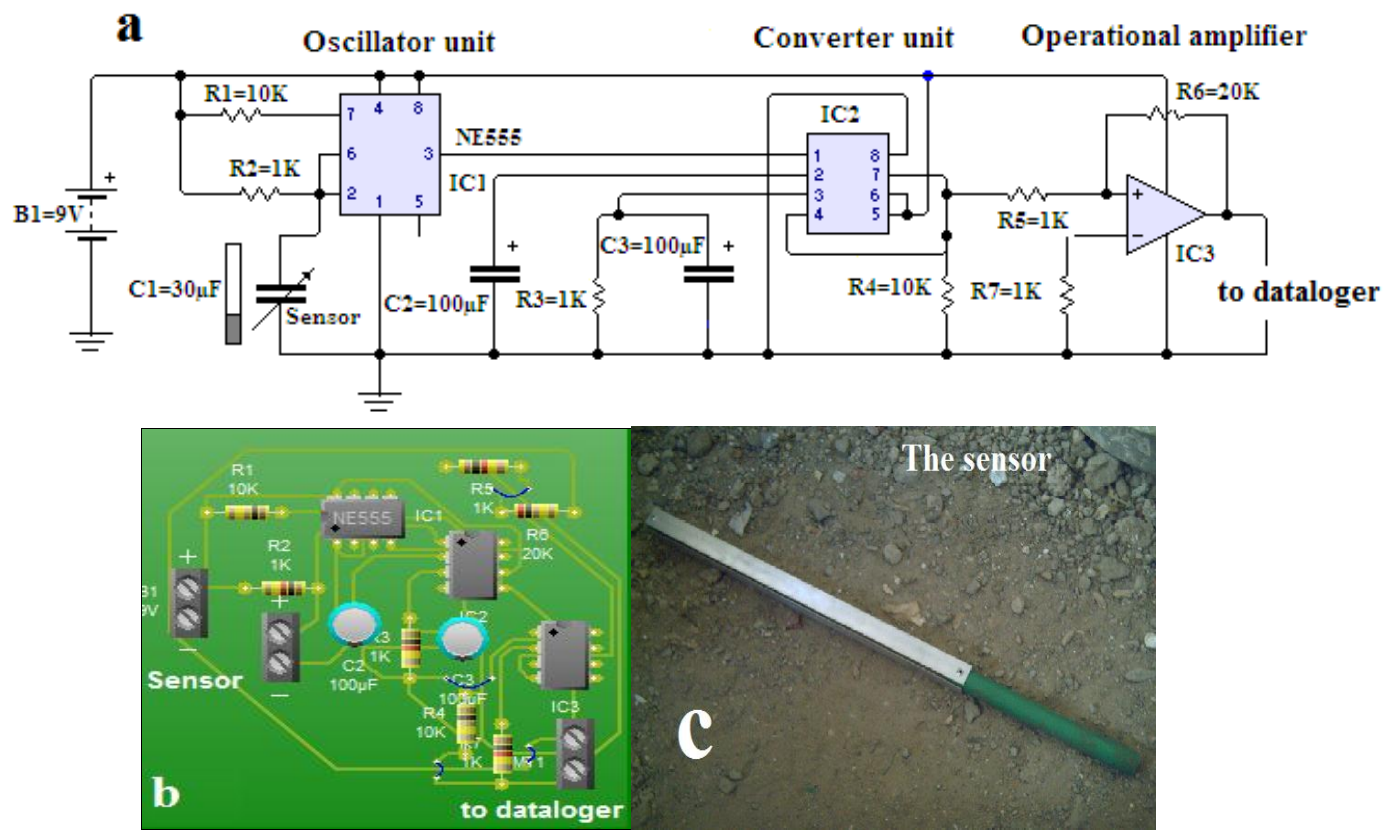

Fig (1): Circuit diagram of the used device and the sensor 
5-The relationship between the outputs results comes out from the sensor

(capacity in $(\mu \mathrm{F})$ ) versus water heights was as shown in Fig. (2).

6-A polynomial is then calculated to fit the data.

7-The fitted equation can be written as follows:

$$
y=8 e^{-06} x^{4}+0.018 x^{2}+0.561 x+0.129
$$

Where $\mathrm{y}$ is the sensor capacity in $\mu \mathrm{F}$ and $\mathrm{x}$ is the water heights in $\mathrm{cm}$.

\section{Field measurements and device testing procedures:}

Field experiments were conducted at a Sugar crops Research stationAlexandria where Sugar beet is grown in clay soils to evaluate the accuracy of the data collected by the device as compared with data measured by traditional method. The soil was classified as clay soil (16.12\% sand, $19.46 \%$ silt and $64.42 \%$ clay). The experimental area was divided into three main plots each was $9 \mathrm{~m}$ wide and $60 \mathrm{~m}$ long as shown in Fig (3). Each plot contains twelve furrows. Each three furrows represented one treatment. A furrow treatment consisted of three furrows with the middle furrow used for monitoring flow rates, advance, recession times and water heights and the outer two were used as buffer furrows. The length, spacing and slope of the furrows monitored were 60 $\mathrm{m}, 0.75 \mathrm{~m}$ and $0.1 \%$, respectively. Furrow length was divided into 6 stations; the distance between each tow successive sensors was equal to $10 \mathrm{~m}$. Six sensors were arranged and installed in the center line of furrow at each station from the upstream end of the furrow along the furrow to cover the whole furrow length, to record the advance, recession times and water heights in furrow irrigation system as shown in Fig (4). Spiels tubes were used to deliver the required inflow rate into the furrows. Three inflow rates, noted $1.14,1.42$ and $2.25(1 / \mathrm{s})$ were used. The treatments were separated by non-irrigated furrows. Furrows adjacent to the furrow being monitored were irrigated simultaneously. This was done to prevent lateral seepage and to provide infiltration conditions similar to a typical furrow irrigation practice. All field operations that may affect the conditions of the furrows were carried out before the start of first irrigation on the experimental site. Measurements of furrow irrigation hydraulic included furrow geometry, slope, width, length, advance time, cut-off time, recession time, and furrow water heights with time using the device through irrigation event for each inflow rate were recorded. (Enciso-Median et al. 1998 and Abbasi et al. 2003). 


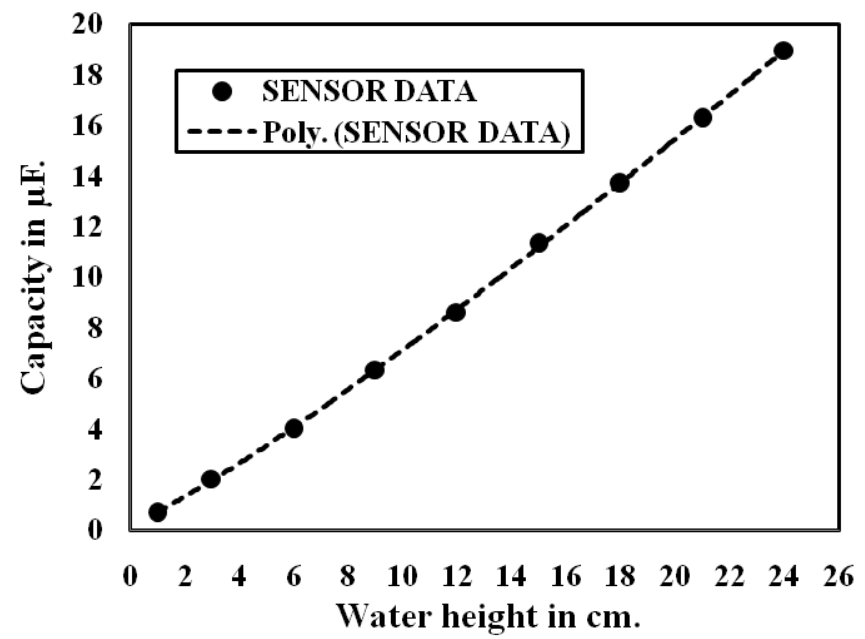

Fig (2): the relationship between the output results comes out

from the sensor (capacity in $\mu \mathrm{F}$ ) versus water heights.

\section{Furrow geometry:}

During furrow evaluation, the cross- sectional geometry was measured at furrow top, middle and bottom. The measurements were taken just before irrigation and three days after irrigation following the method suggested by Walker and Busman (1990).

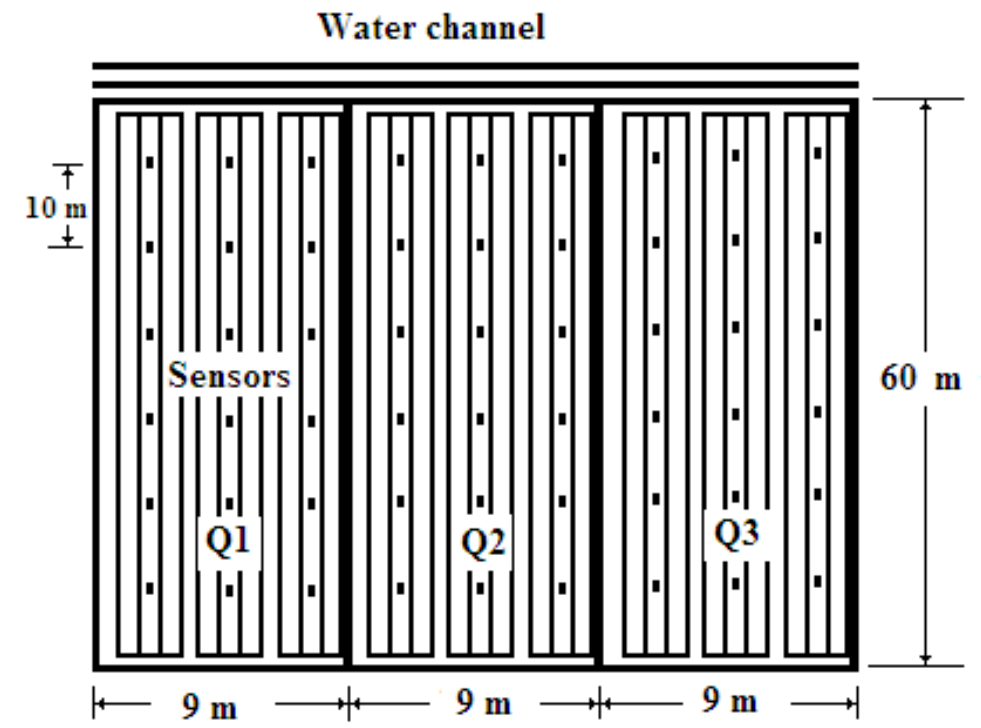

Fig. (3): A plan-view of the experimental site layout with water sensors installed inside and middle of furrows. 


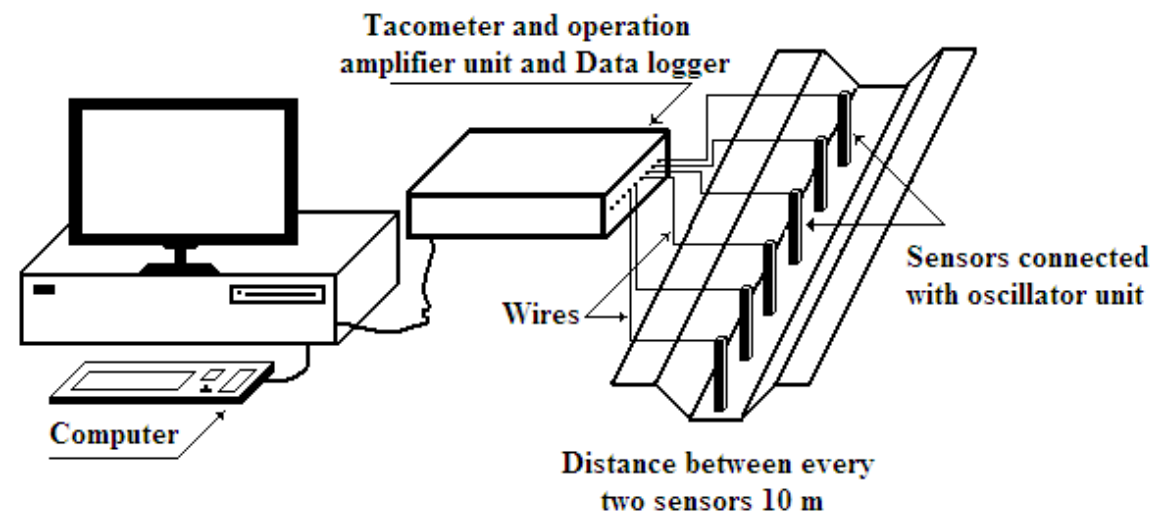

Fig (4): Construction drawing of sensors installed in furrow and the connection between sensors, amplifier and Data logger with computer.

At each station, the rods were lowered until they touched the soil surface. The individual scales on the rods of the profile-meter provided data to plot furrow depth, Y, as function of the lateral distance. Then the depth of the flow, Yy, and the cross- sectional flow area, A, were related mathematically with the power function as described by (Maheshwari et al., 1988) as follows:

$$
\mathrm{Y}=\mathrm{b} \mathrm{A}^{\mathrm{h}}
$$

Where, $\mathrm{b}$ and $\mathrm{h}$ are constants. The wetted perimeter was also determined as a power function of the cross-sectional area (A) using Manning equation as mentioned by Larry (1993) as follows:

$$
\mathrm{A}^{2} R^{4 / 3}=\mathrm{d} \mathrm{A}^{\mathrm{f}}
$$

Where $\mathrm{R}$ is the hydraulic radius, $\mathrm{d}$ and $\mathrm{f}$ are empirical constants. Crosssectional profile data are collected at furrow top, middle and bottom using furrow-profile-meter. These data are then integrated and a geometric relationship is used to relate the cross- sectional area and wetted perimeter with depth. The empirical parameters $b, h, d$ and $f$ were determined throughout the irrigation season using a two-point fit of the data.

\section{Advance and recession time of water over furrow surface.}

The advance of the water front in the test furrows should be monitored. This can be accomplished by recording the time (using stop watch) at 
which the water front reaches each station. The stations should be marked with stakes or flags prior to the irrigation event. Recession times were recorded at the times when water fully infiltrated the soil at the observation sections. Likewise, advance and recession times were self recorded by the sensor. The most important field data are the advance rate, which can vary throughout the irrigation season. The empirical procedure followed for determination of the advance trajectory was based upon the following steps: i) Using field stakes and surveying tape, the tested furrows were divided into a number of stations having equal distances between them. ii) As the irrigation water advanced down the furrow, arrival times were recorded at the end of each reach. Then, the advance trajectory was represented by a power function following a two point procedure as described by Elliott and Walker (1982).

$$
\mathrm{X}=\mathrm{P} \mathrm{t}^{\mathrm{r}}
$$

Where, $\mathrm{X}$ is the advance distance in $\mathrm{m}$, achieved in $\mathrm{t}$ a minutes of inflow. $\mathrm{P}$ and $\mathrm{r}$ are fitting parameters. When the flow area was equal to $10 \%$ of the maximum cross- sectional area, recession times were observed and recorded at each station. Advance and recession time of water over furrow surface during irrigation were also measured using sensors by collecting data stored in data logger.

\section{Water height over furrow surface:}

The depth of flow was measured at every $10 \mathrm{~m}$ interval. Thus in an irrigation of $60 \mathrm{~m}$ length, six sensors were installed (water level) at each station for every 2 minutes by sensors. The average depth of water stored above soil surface was calculated according to Lal and Pandya (1972).The cross-sections area of the furrow is required in estimating water surface storage during irrigation for the optimization method by measuring water heights in the furrow.

\section{Experimental and theoretical approach for measuring water infiltrated volume:}

According to Trout (1992) and Oyonarte et al. (2002), experiments were conducted for measuring infiltrated water volume versus time. This procedure was repeated for each inflow rate over the experimental field plot. Water infiltrated volume at each station was also estimated using a sensor by recording the variations occurs in water levels through 
irrigation events. The difference between every two successive values of water heights at each station through time interval 2 minute, were subtracted. This difference represented to water infiltrated depth at time interval 2 minute. On the same time the volume balance model was used to estimate the cumulative water infiltrated volumes or depths at each station along furrow length. The objective function used in the optimization method is the square of the difference between the volume of water infiltrated as observed in the field and that calculated using an infiltration equation (Maheshwari et al., 1988). For furrow irrigation, the function can be expressed mathematically as follows:

$$
\Delta \mathrm{V}=\sum_{\mathrm{i}=1}^{\mathrm{N}}\left(\mathrm{V}_{\mathrm{oi}}-\mathrm{V}_{\mathrm{ci}}\right)^{2}
$$

Where $\Delta \mathrm{V}$ is the sum of the squares of the differences between $\mathrm{V}_{\mathrm{Oi}}$ and $\mathrm{V}_{\mathrm{Ci}}, \mathrm{V}_{\mathrm{Oi}}$ is the observed volume of water infiltrated in furrow when the water-front reaches the observation point $\mathrm{i}, \mathrm{V}_{\mathrm{Ci}}$ is the calculated volume of water infiltrated in the furrow when the front reaches the observation point $\mathrm{i}$, and $\mathrm{N}$ the number of observation points in the furrow. In order to compute the calculated volume of water infiltrated $\left(\mathrm{V}_{\mathrm{C}}\right)$ at any distance along the furrow, a regression model for the relation between advance distance ( $\mathrm{x}$ ) and time ( $\mathrm{t}$ ) is developed. An advancing water-front will move along the furrow as shown in Fig (5). The infiltration parameters using the volume balance can be calculated conveniently for the time period $\left(t_{a d}\right)$ equal to the time ' $t$ ' when water reaches the end of furrow. It was assumed that this time period is adequate to describe the infiltration parameters. The period $t$, is divided into ' $n$ ' equal increments $(\Delta t)$ with $\Delta \mathrm{x}_{1}, \Delta \mathrm{x}_{2}, \ldots \ldots, \Delta \mathrm{X}_{\mathrm{i}}$, the incremental advance distances at times $1 \Delta \mathrm{t}, 2 \Delta \mathrm{t}$, $\ldots \ldots$, i $\Delta \mathrm{t}$. Assume that $\mathrm{Z}_{1}, \mathrm{Z}_{2}, \ldots \ldots \mathrm{Z}_{\mathrm{i}}$ are the volumes of infiltration per unit length of furrow based on 'instantaneous' infiltration rates at infiltration opportunity times equal to $1 \mathrm{At}, 2 \mathrm{At}, \ldots$, iAt. Let us assume that $\check{Z}_{1}, \breve{Z}_{2}, \ldots \ldots, \breve{Z}_{i}$ are the volumes of infiltration per unit length of furrow based on 'instantaneous' infiltration rates at infiltration opportunity times equal to $1 \Delta \mathrm{t}, 2 \Delta \mathrm{t} \ldots \ldots, \mathrm{i} \Delta \mathrm{t}$, and $\mathrm{Z}_{1}, \mathrm{Z}_{2}, \ldots \ldots \mathrm{Z}_{\mathrm{i}}$ are the average volumes of infiltration per unit length for incremental distances $\Delta \mathrm{x}_{\mathrm{i}}, \Delta \mathrm{x}_{\mathrm{i}-1} \ldots \ldots, \Delta \mathrm{x}_{\mathrm{I}}$, along the furrow. The infiltration opportunity time for 
$\Delta \mathrm{x}_{1}$ varies from 0 to $1 \Delta \mathrm{t}$ and therefore the value of $\check{Z}_{1}$, can be calculated using modified Kostiakov equation that expressed by (Esfandiari and Maheshwari 1997) as follows:

$$
\overline{\mathrm{Z}}_{\mathrm{I}}=\frac{1}{\Delta \mathrm{t}} \int_{0}^{\Delta \mathrm{t}}\left(\mathrm{kt} \mathrm{a}^{\mathrm{a}}+\mathrm{bt}\right) \mathrm{dt}
$$

or:

$$
\overline{\mathrm{Z}}_{1}=\frac{\mathrm{k}}{\mathrm{a}+1}(\Delta \mathrm{t})^{a}+\frac{\mathrm{b}}{2} \Delta \mathrm{t}
$$

The values of $\check{Z}_{2}, \check{Z}_{3}, \ldots . . \check{Z}_{i}$ are calculated as an average of consecutive $\mathrm{Z}$ values i.e. $\left(\check{Z}_{2}=\left(\mathrm{Z}_{1}+\mathrm{Z}_{2}\right) / 2, \breve{Z}_{3}=\left(\mathrm{Z}_{2}+\mathrm{Z}_{3}\right) / 2, \ldots \ldots \check{Z}_{\mathrm{i}}=\left(\mathrm{Z}_{\mathrm{i}-1}+\mathrm{Z}_{\mathrm{i}}\right) / 2\right)$. The calculated volume of water infiltrated $\left(V_{C}\right)$ at $t=1 \Delta t$ is given by:

$$
\mathrm{V}_{\mathrm{C} 1}=\Delta \mathrm{x}_{1} \Delta \overline{\mathrm{Z}}_{1}
$$

and at $t=i \Delta t$

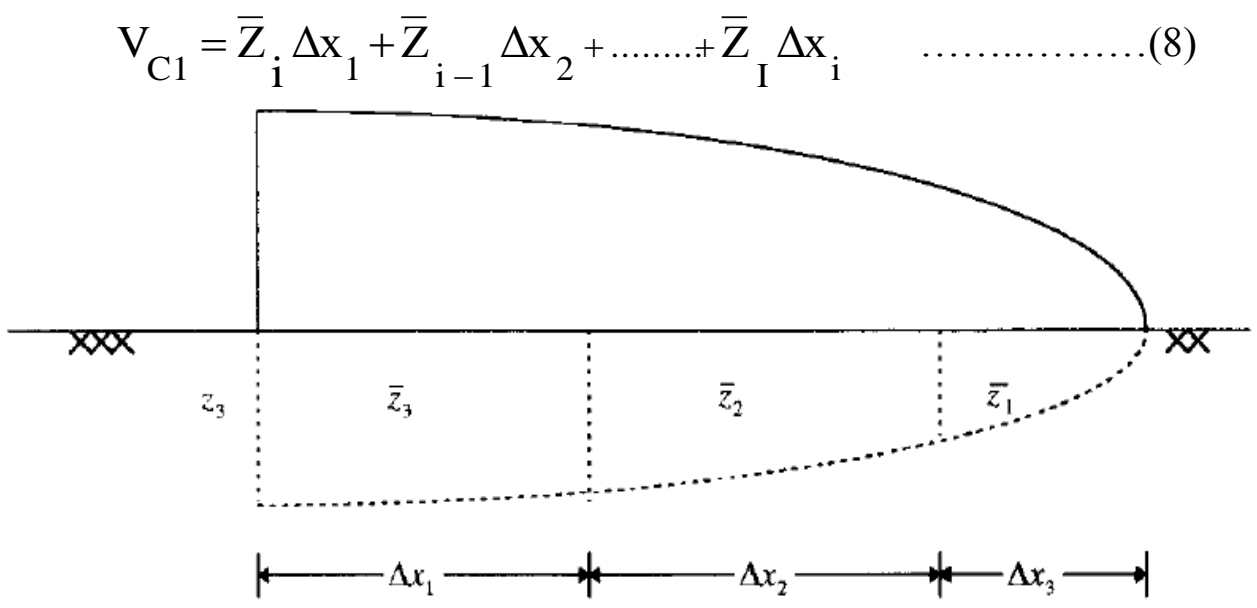

Fig. (5). Advancing water-front and water infiltrated volume under different time intervals.

The main input data required in the method are inflow rate, flow area at the inlet of furrow and elapsed times for advancing the water-front to the middle and end of furrow. Based on the analysis of the volume balance equation at two points (Elliott and Walker, 1982), the parameters ' $k$ ' and ' $\mathrm{a}$ ' are determined as follows:

$$
\mathrm{a}=\frac{\mathrm{Ln}\left\lfloor\left(\mathrm{Q}_{\mathrm{o}} \mathrm{t}_{\mathrm{L}} / \mathrm{L}-\sigma_{\mathrm{y}} \mathrm{A}_{\mathrm{o}}-\left(\mathrm{bt}_{\mathrm{L}}\right) /(1+\mathrm{r})\right) /\left(2 \mathrm{Q}_{\mathrm{o}} \mathrm{t}_{0.5 \mathrm{~L}} / \mathrm{L}-\sigma_{\mathrm{y}} \mathrm{A}_{\mathrm{o}}-\left(\mathrm{bt}_{0.5 \mathrm{~L}}\right) /(1+\mathrm{r})\right)\right\rfloor}{\operatorname{Ln}\left(\mathrm{t}_{\mathrm{L}} / \mathrm{t}_{0.5 \mathrm{~L}}\right)}
$$


and

$$
\mathrm{K}=\frac{\left(\mathrm{Q}_{\mathrm{o}} \mathrm{t}_{\mathrm{L}} / \mathrm{L}-\sigma_{\mathrm{y}} \mathrm{A}_{\mathrm{o}}-\left(\mathrm{bt}_{\mathrm{L}}\right) /(1+\mathrm{r})\right.}{\sigma_{\mathrm{Z}} \mathrm{t}_{\mathrm{L}}{ }^{\mathrm{a}}}
$$

where A, is the cross-sectional area of flow at the inlet (m'), Q, the inflow rate $\left(\mathrm{m}^{3} / \mathrm{min}\right), \sigma_{\mathrm{y}}$ the surface storage shape factor, which is defined as a constant of 0.7 to $0.8, \mathrm{t}_{\mathrm{L}}$, advance time to the end of the field (min), $\mathrm{t}_{0.5 \mathrm{~L}}$, the advance time to one-half the field length (min), $L$ the field length $(\mathrm{m})$ and $\sigma_{\mathrm{Z}}$ the subsurface shape factor, defined as

$$
\sigma_{z}=\frac{a+r(1-a)+1}{(1+a)(1+r)}
$$

The value of ' $b$ ' is determined by inflow-outflow method (Elliott and Walker, 1982) as follows:

$$
\mathrm{b}=\frac{\mathrm{Q}_{\text {in }}-\mathrm{Q}_{\text {out }}}{\mathrm{L}}
$$

Where $\mathrm{Q}_{\text {in }}$, and $\mathrm{Q}_{\text {out }}$ are inflow and outflow rates respectively, in $\mathrm{m} 3 / \mathrm{min}$ when the values of inflow and outflow become constant.

\section{RESULTS AND DISCUSSION}

\section{Water advance and recession times as affected by inflow rates:}

In order to define the inflow discharge $(\mathrm{Q})$ to be applied in the furrow irrigation method, three irrigation tests were conducted in which discharge varied from 1.14 to 2.25 (1/s). Fig. (6) shows water advance and recession curves. They are differing for each used flow rate as expected, (similar results were found in several works, for example Bassett et al. 1983). As shown in Fig. (6), total advance times $\left(t_{L}\right)$ were recorded as 56.0, 42.4, and $30.5 \mathrm{~min}$ at $1.14,1.42$, and $2.25(1 / \mathrm{s})$ inflow rates, respectively. Total recession time $\left(t_{R}\right)$ were found to be 70.0, 53.4, and $46.0 \mathrm{~min}$ for the same inflow rate, respectively. In addition the results showed that the lower $\mathrm{Q}$ has a lower water speed therefore water had more time to infiltrate, and this creates a larger water table at the beginning of the furrow and a poor distribution of soil moisture along the furrow. Curves in Fig (6) showed that advance and recession times were decreased by increasing their inflow rates. On the contrary, depletion 
phase time was increased with the increase of inflow rate due to reducing the advance stage duration when water was applied. The value of advance time decreased as inflow rate increase, this was due to fast movement of water in horizontal direction than infiltrate it in vertical direction. Also, the recession time increased as inflow rate increased, this can be explained that increasing inflow rate, water infiltrated into soil takes more time to disappear.

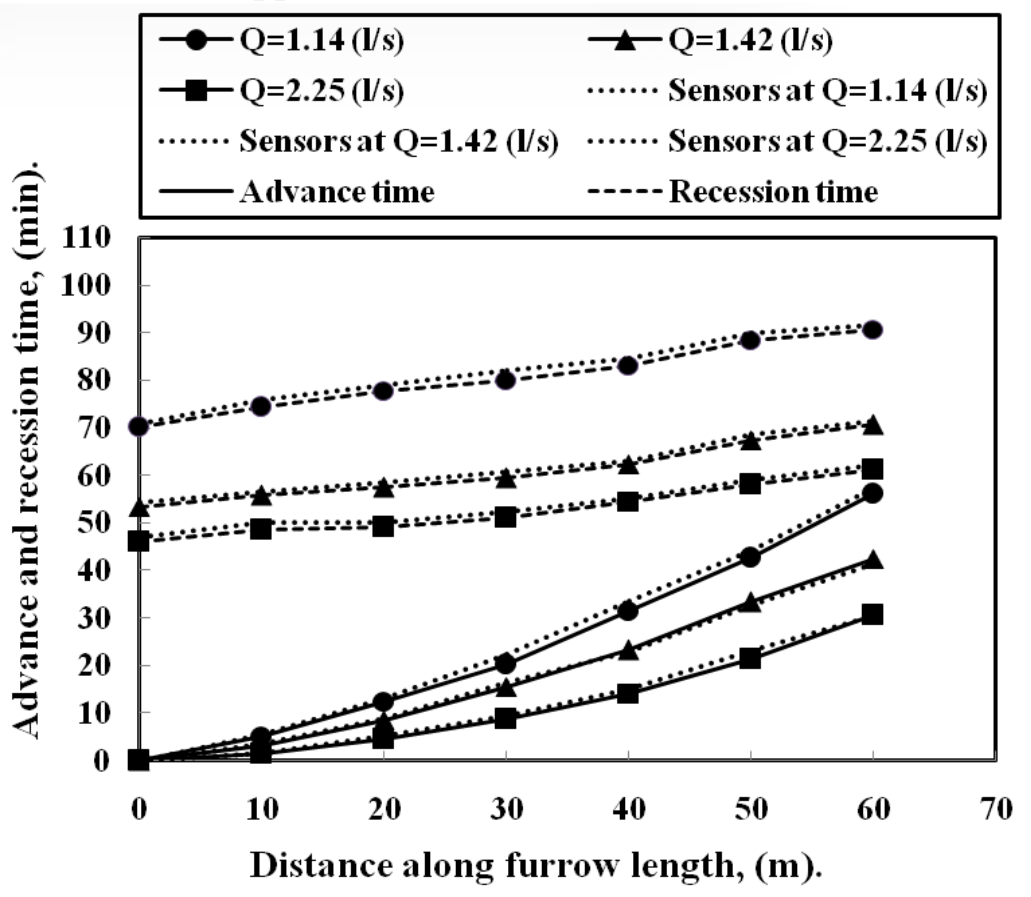

Fig. (6). Water advance and recession times obtained from traditional and sensors methods under different inflow rates.

\section{Water infiltrated volume as affected by inflow rates:}

Furrow water infiltrated volume as affected by three inflow rates was observed $\left(\mathrm{V}_{\mathrm{obs}}\right)$ by measuring water height inside and in middle furrow through irrigation events. For applying the method in furrow irrigation, the parameters $\left(\mathrm{V}_{\text {obs }}\right)$ was calculated in a manner similar to the border method except that the cross section of flow differed in the furrow method due to the furrow shape, Maheshwari et al. (1988). 
Modified Kostiakov equation for water infiltrated volume $\left(\mathrm{V}_{\mathrm{Cal}}\right)$ in furrow irrigation using different inflow rates was calculated and the equation was expressed as: $\mathrm{Z}=0.0092 \mathrm{t}^{0.184}+0.00058 \mathrm{t}$. The calculated total volume of water infiltrated in the furrow, determined using the modified Kostiakov infiltration equation and fitted by the optimization. Fig (7) shows a Plot of total volume of water infiltrated that calculated $\left(\mathrm{V}_{\mathrm{Ci}}\right)$ using optimization method of estimating infiltration characteristics for different irrigation events, Clemmens, A.J., (2007). Also, Fig (7) showed that water infiltrated volume was increased when inflow rate was low due to slow water movement along furrow. Maximum calculated infiltrated volume $\left(\mathrm{V}_{\mathrm{Cal}}\right)$ where occurred at the upstream end, its values were $0.515,0.424$, and 0.346 ( $\mathrm{m}^{3} /$ furrow length) by applying $1.14,1.42$, and $2.25(1 / \mathrm{s})$ inflow rate, respectively. On the other hand, minimum calculated infiltrated volume $\left(\mathrm{V}_{\mathrm{Cal}}\right)$ where occurred at the downstream end and its values were equal to $0.353,0.299$, and $0.271 \mathrm{~m}^{3} /$ furrow length), by applying the same inflow rates, respectively. These results confirmed with Amer (2007). Maximum water infiltrated volumes by applying $1.14,1.420$ and $2.25(1 / \mathrm{s})$ were occurred at downstream end because total advance time $\left(t_{L}\right)$ was larger than total recession time $\left(t_{R}\right)$.

Distance along furrow length, $(\mathrm{m})$.

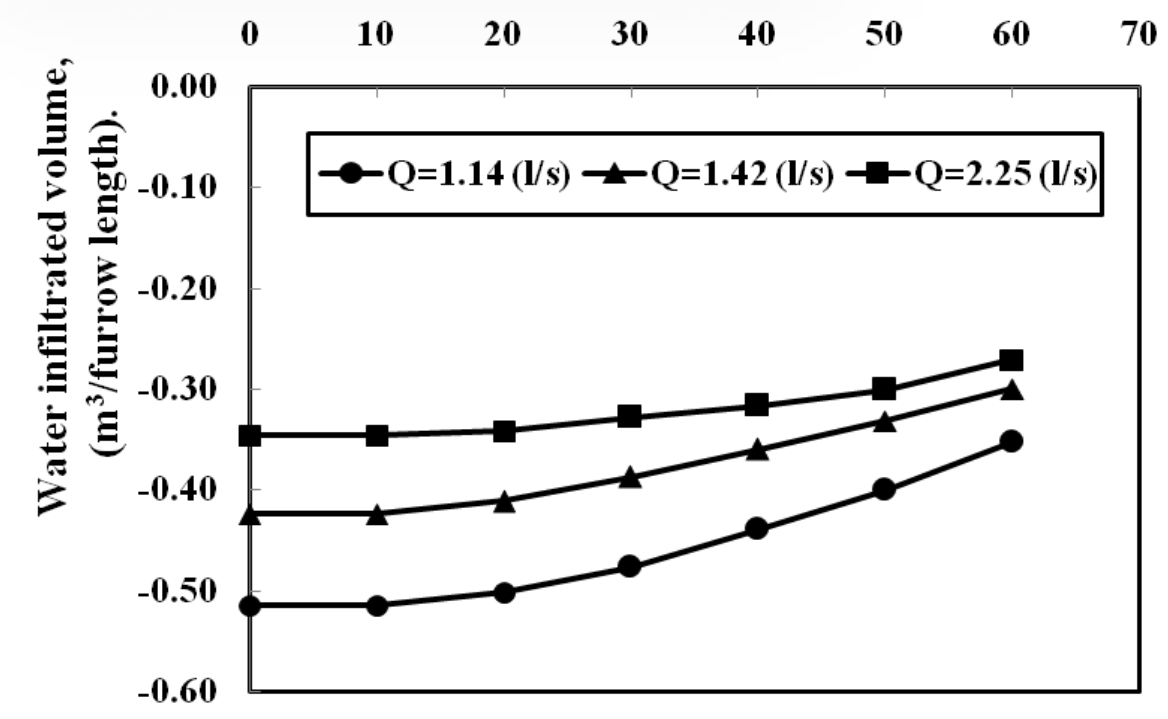

Fig. (7). The calculated total volume of water infiltrated $\left(\mathrm{V}_{\mathrm{Ci}}\right)$ using optimization method for different irrigation events. 


\section{Model Verification}

\section{Advance and recession times:}

The advance and recession time are shown in Fig. (6), for different treatment under different inflow rates. It is obvious that, both of advance and recession times come out from water sensors (dash line) were higher as compared with traditional method (solid line). Verification is made here to test the used device (sensors) behavior in comparison to traditional method. For short furrows $(60 \mathrm{~m})$ the behavior of advance time data by sensors is typical and so close to traditional method with deviate a little. This means that, the used device (sensors) was succeeded in recording data by itself with high accuracy instead of measuring data by stopwatch.

\section{Water infiltrated volume:}

The accuracy of estimating infiltration characteristics in furrow irrigation were evaluated by comparing the calculated total volume of water infiltrated into the furrow based on the fitted by the optimization infiltration equation with that observed in the field. Figs (8) through (10) showed that, the data for all the irrigation events with the optimization method fall very close to the $45^{\circ}$ line degree. The goodness of fit of the above equation to data is usually determined by calculating the coefficient of determination $\left(\mathrm{R}^{2}\right)$ and the absolute error, $(\mathrm{E})$, The values of the coefficient of determination $\left(\mathrm{R}^{2}\right)$ for water infiltrated volume, were determined and were found to be $0.953,0.936$, and 0.942 for inflow rates $1.14,1.42$, and $2.25(1 / \mathrm{s})$, respectively. This means that, high correlation between measured and calculated values. Also, the absolute error, (E), in percentage was computed for each inflow rate to measure the goodness of fit and is given as:

$$
E=\left[\frac{A B S\left(V_{\text {obs }}-V_{c a l}\right)}{V_{\text {obs }}}\right] \times 100
$$




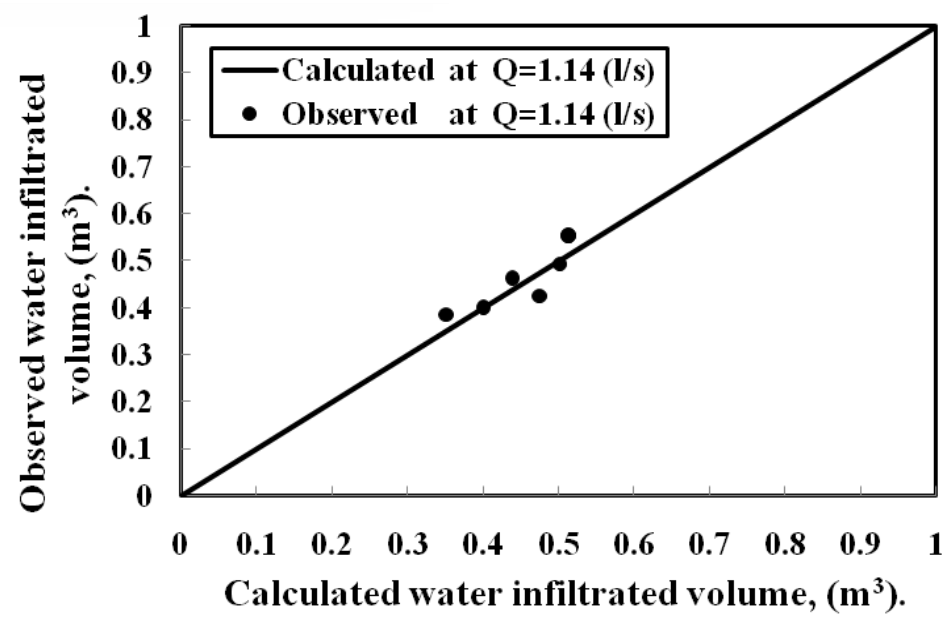

Fig.(8). Volume of water infiltrated observed $\left(V_{\text {obs }}\right)$ versus calculated $\left(V_{\text {cal }}\right)$ using optimization method for inflow rate $1.14(\mathrm{l} / \mathrm{s})$.

The values of the absolute error, (E) for water infiltrated volume, were determined using optimization technique and were found to be 0.069 , 0.065 , and $0.077 \%$, for inflow rates $1.14,1.42$, and $2.25(1 / \mathrm{s})$, respectively. This means, the optimization method is expected to be superior for estimating infiltration characteristics, especially for evaluating furrow irrigation models. In addition to its high accuracy, the method is capable of using any form advance function and infiltration equation and does not require field measurement of basic infiltration rate.

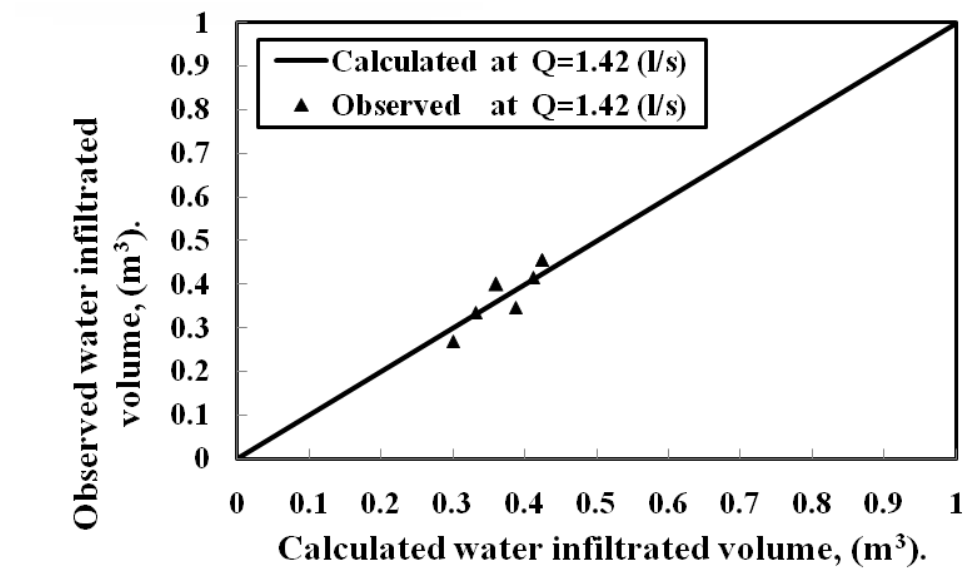

Fig.(9). Volume of water infiltrated observed $\left(V_{\text {obs }}\right)$ versus calculated ( $\left.V_{\text {cal }}\right)$ using optimization method for inflow rate $1.42(1 / s)$. 


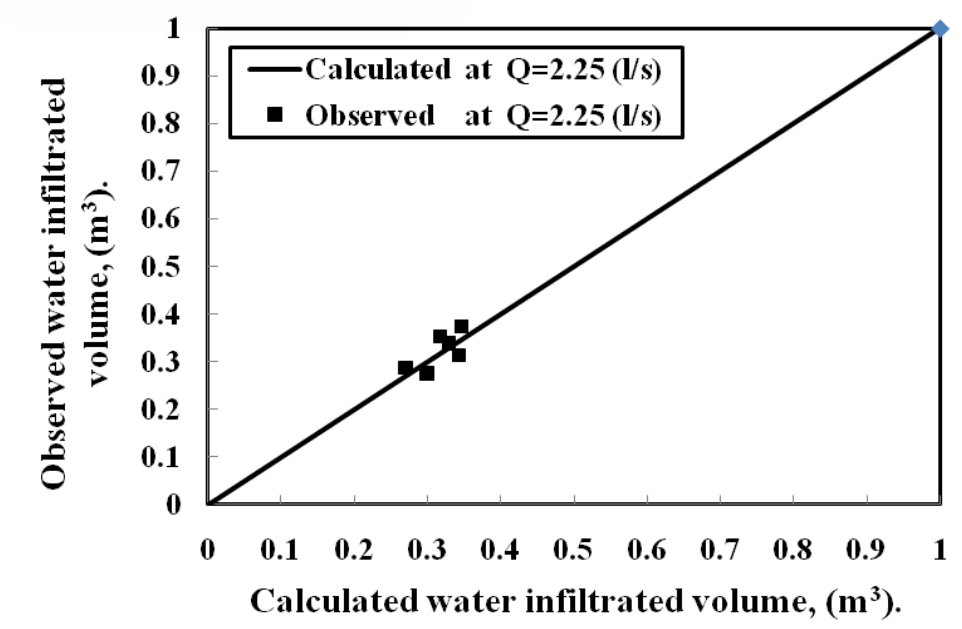

Fig.(10). Volume of water infiltrated observed $\left(V_{\text {obs }}\right)$ versus calculated $\left(\mathrm{V}_{\text {cal }}\right)$ using optimization method for inflow rate $2.25(1 / \mathrm{s})$.

\section{CONCLUSION}

The main target of this research is to design simple electronic device for measuring both advance and recession times, and furrow water depth through irrigation event. Volume balance method was applied to estimate infiltration characteristics in furrow irrigation based on a specific form of the advance function and or the infiltration equation which can be restrictive for field use in many situations.

Comparison of the calculated water infiltrated volume with observed reveals that:

1-The behavior of advance phase for short furrow $(60 \mathrm{~m})$ measured by a simple electronic device (sensors) is typical and so close to that obtained by traditional method with deviate a little.

2-The verification results between calculated versus observed water infiltrated volume by modified optimization using modified Kostiakov, fall very close to $45^{\circ}$ line degree with deviate a little.

3-The goodness of fit data mean that modified optimization method may sound superior for estimating infiltration characteristics, especially for evaluating furrow irrigation system with high accuracy.

4-For future research it is important to improve the deigned device, it strongly recommended to evaluate and test sensitivity of the device for border and basin irrigation systems. 


\section{REFERENCES}

Abbasi, F., F. J. Adamsen, D. J. Hunsker, J. Shouse and M. Th Van Genuchten. (2003). Effects of flow depth on water flow and solute transport in furrow irrigation: Field data analysis. J. Irrig . and Drain. Eng. ASCE, (129): 237-246.

Amer, K.H. (2007). Surface irrigation evaluation based on analytical interrelation among water infiltration, advance, and recession. Proceeding of Irrigation Association, 9-11 Dec in San Diego, CA: 433-445.

Ampas, V. and E. Baltas. (2009) Optimization of the furrow irrigation efficiency. Global NEST Journal, 11 (4) : 566-574.

Bassett, L. D., D. D. Frangmeier and T. Strelkoff . (1983). Hydraulics of Surface Irrigation, In: Design and Operation of Farm Irrigation Systems, Edited by Jensen, ASAE, PP: 449-498.

Clemmens, A.J.( 2007) Simple approach to surface irrigation design Theory. Journal of Land and Water. 1: 1-19.

Elliott, R. L. and W. R. Walker. (1982). Field evaluation of furrow infiltration and advance functions. Trans. of the ASAE, (25): 396400.

Esfandiari, M. and B. L. Maheshwari. (1997). Application of the optimization method for estimating infiltration characteristics in furrow irrigation and its comparison with other methods. Agricultural Water Management 34: 169-185.

Forrest M. Mimis. (1989) .Engineer's Mini -Notebook SSS timer IC circuits, cat. No. 276-5010.

Hunsaker, D.J., D.E. Pettit, and A.J. Clemmens. (2011). A-self-contained probe for measuring water advance and recession times in surface irrigated fields. App. Eng. In Agric. 27 (5): 729-736.

Lal, R. and A. C. Pandya. (1972). Volume balance method for computing infiltration rates in surface irrigation. Trans., ASAE, 15: 69-72.

Larry G. James (1993). Principles of farm irrigation system design. Krieger publishing company Malabar, Florida. PP:301:381. 
Maheshwari, B.L., A.K. Turner, T.A. McMahon and B.J. Campbell . (1988). An optimization technique for estimating infiltration characteristics in border irrigation. Agric. Water Manage. 13:1324.

Oyonarte, N. A., L. Mateos and M. J. Palomo. (2002). Infiltration variability in furrow infiltration. J. Irrig. and Drain.Eng., ASCE, 128: 26-33.

Strelkoff, T. and F. Souza. (1984) Modeling effect of depth on furrow irrigation. J. Irrig. Drain Eng., 110(4):375-387.

Trout, T. J. (1992). Flow velocity and wetted perim effects on furrow infiltration, Trans. Of the ASAE, (35): 855-862.

Walker, W.R. and J.D. Busman (1990). Real-time estimation of furrow infiltration. Journal of Irrigation and Drainage Eng., ASCE, 116(3): 299-318.

Wöhling, Th., R. Singh, and G. H. Schmitz. (2004). Physically based modeling of interacting surface-subsurface flow during furrow irrigation advance. J. Irrig. Drain. Eng., 130(5) : 349-356.

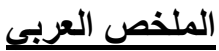

جهاز ألكتروني بسيط لقياس زمن تقدم وعمق المياه في نظام الري بالخطوط

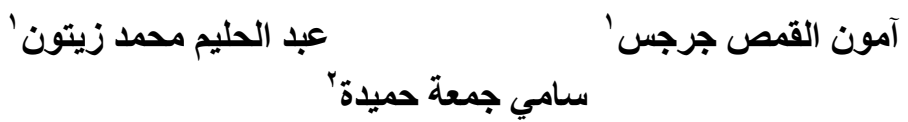

يهدف البحث الي تصميم جهاز الكثروني دقيق وبسيط ذو حساسية عاليـة وسهل الأستخدام في الفي

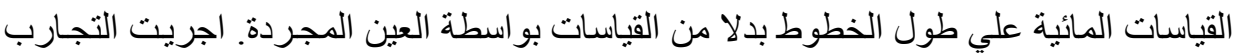

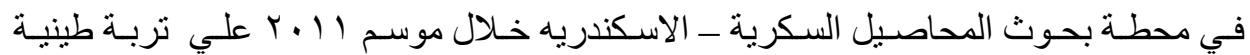

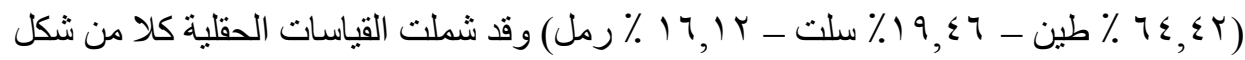
وطول و عرض الخطوطو ميل الأرض في اتجاه الري بالإضافة الي زمن تقدم وانحسار المياه

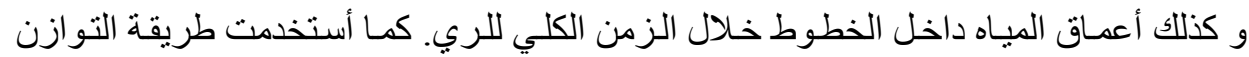

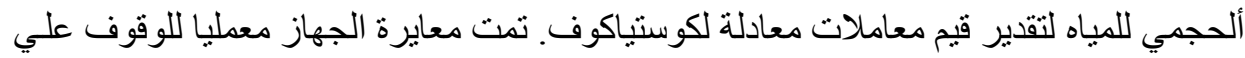

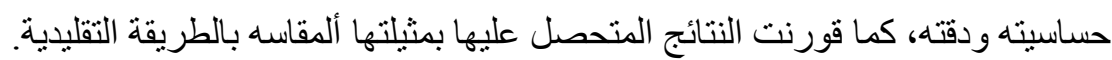

$$
\begin{aligned}
& \text { باحث أول' بمعهد بحوث الهندسة الزراعية ـ مركز البحوث الزراعية ـ الجيزة. }
\end{aligned}
$$

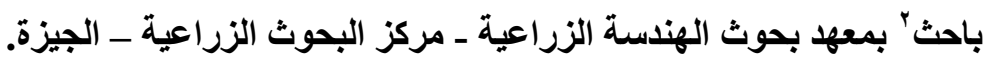




\section{و كانت أهم النتائج المتحصل عليها:}

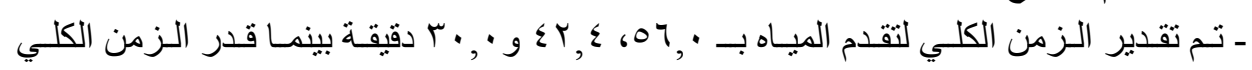

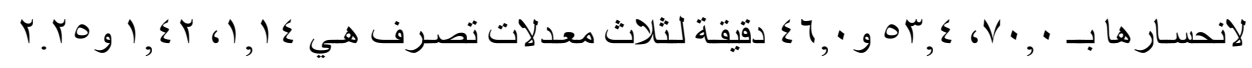

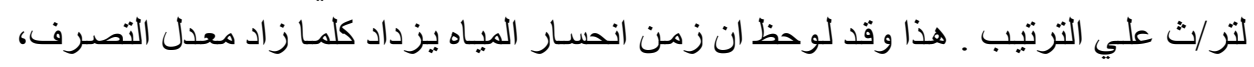
ويرجع هذا الي أن المياه المتسربة تأخذ وقتا أطول لانحسار ها. - ز زادت أحجام المياه المتسربة كلما قل معدل التصرف .و هذا يرجع الي أن تقدم المياه في الاتجـاه

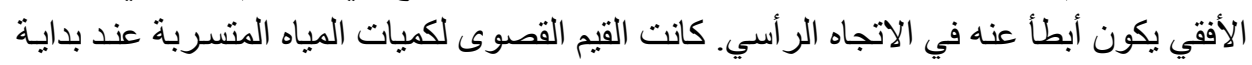

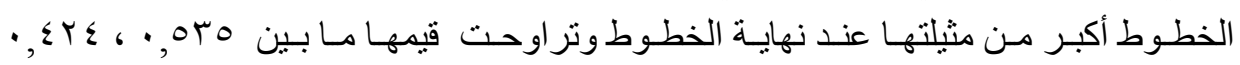

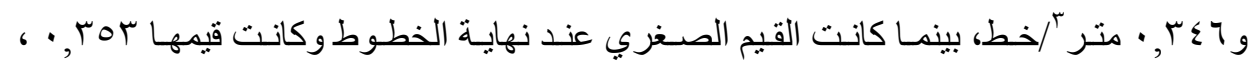

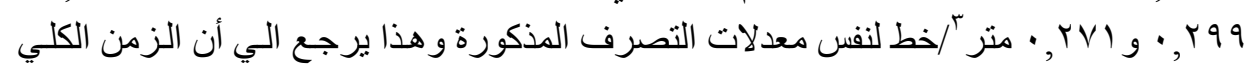
لتقدم المياه يكون أكبر من الزمن الكلي لانحسار المياه. ـ أوضح اختبار الحساسية للقيم المقاسة والمحسوبة لأحجام المياه المتسربة أن جميع النتائج كانت

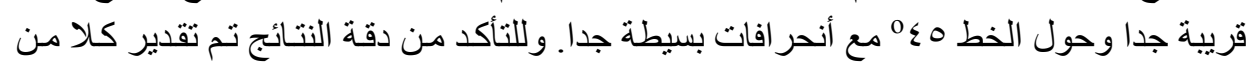

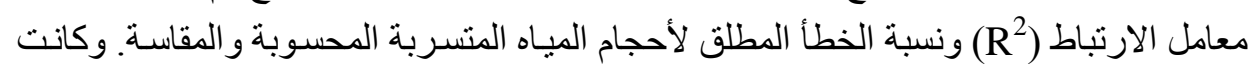

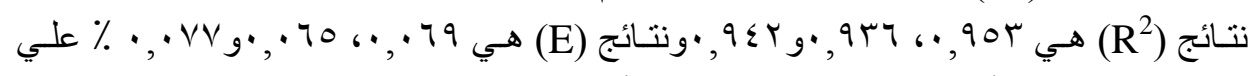
الترتيب و هذا يعني أن طريقة التقنية المستخدمة أكثر كفاءة في تقدير المعاملات تحت الدي الدراستة وبدقة عالية. 